\title{
The role of the globalisation process on mitigation of carbon dioxide emissions in Latin American \& Caribbean countries
}

\section{O papel do processo de globalização na mitigação das emissões de dióxido de carbono nos países da América Latina e Caribe}

\author{
1 Matheus Koengkan matheuskoen@utad.pt \\ 2 José Alberto Fuinhas
}

\begin{abstract}
$1 \mathrm{PhD}$ in (Economics) at the University of Évora, Évora (Portugal), Masters (in Economics) from the University of Beira Interior. He is a researcher in the areas of Latin American and the Caribbean studies, macroeconomics, energy economics and environmental economics at Center for Advanced Studies in Management and Economics of the Universidade de Évora (CEFAGE-UÉ). He has published in international journals, such as Energy; Environmental Economics and Policy Studies; Environmental Science and Pollution Research; and Environment Systems and Decisions. CEFAGE-UE and Department of Economics, University of Évora, Évora, Portugal. Rectory, University of Trás-os-Montes and Alto Douro,Vila Real, Portugal.

$2 \mathrm{PhD}$ (in Economics) is a professor of monetary and financial economics, and intermediate econometrics at the Faculty of Economics, University of Coimbra (Portugal). He is a researcher in the areas of macroeconomics and energy economics, at the (CeBER) - Centre for Business and Economics Research, and (NECE-UBI) - Research Unit in Business Science and Economics, sponsored by the Portuguese Foundation for the Development of Science and Technology. He has published in international journals, such as Energy, Economic Modelling; Energy Policy; and Energy Economics. NECE-UBI, CeBER, and Faculty of Economics, University of Coimbra,Coimbra,Portugal.
\end{abstract}

\begin{abstract}
The impact of globalisation on carbon dioxide emissions was analysed in panel data in thirteen LAC countries for the period from 1991 to 2012. A panel autoregressive distributed lag methodology was used to decompose the total effects of globalisation on carbon dioxide emissions both in short- and long-run components. There is evidence that globalisation contributes to reduce carbon dioxide emissions in the long-run. A possible explanation for this result is that the process of globalisation causes technological enhancement in LAC countries, which contributes to a decrease in environmental degradation. Globalisation has other implications, such as the transfer of responsibility from the state to the private sector, this transfer corresponds to the shifting of regulatory attributes to independent governmental regulatory authorities, in other words, "regulation for competition".
\end{abstract}

\section{Keywords:}

Energy. Climate change. Globalisation. Renewable energy. Policies.

\section{RESUMO}

O impacto da globalização nas emissões de dióxido de carbono foi analisado em dados de painel de treze países da América Latina e Caribe para o período de 1991 a 2012. Uma metodologia de atraso distribuído auto-regressivo em painel foi usada para decompor os efeitos totais da globalização nas emissões de dióxido de carbono, tanto em curto quanto em longo prazo. Há evidências de que a globalização contribui para reduzir as emissões de dióxido de carbono a longo prazo. Uma possível explicação para esse resultado é que o processo de globalização causa aprimoramento tecnológico nos países da América Latina e Caribe, o que contribui para a diminuição da degradação ambiental. A globalização tem outras implicações, como a transferência de responsabilidade do estado para o setor privado, essa transferência corresponde à mudança de atributos regulatórios para autoridades reguladoras governamentais independentes, ou seja, "regulamentação para concorrência".

\section{Palavras-chave:}

Energia. Alterações Climáticas. Globalização. Energia renovável. Políticas.

\section{Como você deve citar?}

KOENGKAN, Matheus; FUINHAS, José Alberto. The role of the globalisation process on mitigation of carbon dioxide emissions in Latin American \& Caribbean countries. Cadernos UniFOA, Volta Redonda, n. 45, p. 107-118, abril 2021. 


\section{INTRODUCTION}

Economic growth, higher population density and the consumption of fossil fuels have all influenced the increase in carbon dioxide emissions $\left(\mathrm{CO}_{2}\right)$ in the last two decades (MAGAZZINO, 2014). Latin American and Caribbean (LAC) countries have seen $\mathrm{CO}_{2}$ emissions more than double in the last three decades (AL-MULALI et al., 2015).

In LAC countries, environmental degradation has been directly related to changes in their economic structure, in which some agricultural countries in the LAC region have become industrialised economies. This change has undoubtedly contributed to increase environmental degradation, such as loss of biodiversity, depletion of natural resources, deforestation, and desertification, as has been recognized for some time (GROSSMAN; KRUEGER, 1991).

The increase of industrialisation in LAC countries has been caused by aspects of globalisation, such as free trade agreements, and financial openness (ZILIO, 2012). In the 1990s, the first half of the 2000s, and from 2008-2009, the region suffered several financial crises. The best known of these crises were the Mexican crisis from 1994 to 1995, the Brazilian crisis in 1999, the Argentine crisis from 2001 to 2002, the Uruguayan crisis in 2002, and the Subprime crisis from 2008 to 2009 . Those crises were associated with their market reforms and the opening up of their economies (EDWARDS, 2008).

This study aims to answer the following question: is globalisation influencing carbon dioxide emissions? To answer this question, the impact of globalisation on $\mathrm{CO}_{2}$ emissions will be analysed in thirteen LAC countries from 1991 to 2012, using a panel Auto-Regressive Distributive Lag (ARDL) model.

In literature, the impact of globalisation on $\mathrm{CO}_{2}$ emissions has been widely researched. For instance, some empirical studies point out that globalisation decrease $\mathrm{CO}_{2}$ emissions, as the progress of globalisation causes technological advances, which, in turn, contributes to decrease the intensity of environmental degradation (BELADI; OLADI, 2011; SHAHBAZ et al., 2016; HALICIOGLU; KETENCI, 2016). Other studies indicate that globalisation increases emissions, where globalisation gives rise to industrialization and demand for energy from fossil fuels (SHAHBAZ et al., 2013; SHAHBAZ et al., 2014; SHAHBAZ et al. 2017). These studies exemplify the inconsistent conclusions reached on the impact of globalisation on $\mathrm{CO}_{2}$ emissions.

The study of this subject is crucial to understand the real behaviour and impact of globalisation on $\mathrm{CO}_{2}$ emissions in the LAC region because few academic studies seem to investigate the impact of globalisation on $\mathrm{CO}_{2}$. The choice of LAC countries is further justified because it is a region in a constant process of globalisation.

\section{DATA AND METHODOLOGY}

This section is divided into two parts. In the first part, the data used is presented; and in the second part, the econometric methodology is set out.

\subsection{Data}

Annual data from 1991 to 2012 was applied to a panel of thirteen countries, namely: Argentina, Belize, Bolivia, Brazil, Chile, Colombia, Dominican Republic, Ecuador, Jamaica, Mexico, Nicaragua, Peru, and Uruguay. The variables used here were: (i) Carbon Dioxide Emissions $\left(\mathrm{CO}_{2}\right)$ from energy consumption - electric power sector, in million metric tons, and expressed per capita; (ii) Index of Globalisation, 
computed by adding the economic globalisation, social globalisation and political globalisation indices; (iii) Renewable Electricity, consumption in billion Kilowatt-hours from hydroelectric, geothermal, wind, solar, tide, wave, biomass, and waste sources, expressed per capita; (iv) Primary energy consumption in quadrillion Btu from fossil fuels and other sources and expressed per capita, and (v) Gross domestic product (GDP) in constant local currency unity (LCU) and expressed per capita. Table 1 shows the variables' description and descriptive statistics.

Table 1 - Variables' description and descriptive statistics

\begin{tabular}{llrrrrr}
\hline \multirow{2}{*}{ Variables } & \multicolumn{1}{c}{ Description } & \multicolumn{4}{c}{ Descriptive Statistics } \\
\cline { 3 - 7 } LCO2 & Carbon Dioxide Emissions (CO2) & Obs. & Mean & Std. Dev. & Min & Max \\
\hline LIG & Index of Globalisation & 286 & -13.146 & 5.5640 & -14.6043 & -12.2119 \\
\hline LRE & Renewable Electricity Consumption & 286 & -14.5456 & 1.0203 & -16.8644 & -12.7685 \\
\hline LPE & Primary Energy Consumption & 286 & -17.1501 & 5.5938 & -18.6029 & -16.2434 \\
\hline LY & Gross Domestic Product (GDP) & 286 & 10.8586 & 2.4853 & 7.7480 & 16.1225 \\
\hline
\end{tabular}

Notes: Obs. denotes the number of observations; Std.-Dev. denotes the Standard Deviation, Min. and Max. denote "Minimum" and "Maximum", respectively; (L) de-notes variable in natural logarithms.

Fonte:

All variables, except index globalisation, were transformed in per capita values. The use of per capita values lets us control disparities in population growth among the Latin American and Caribbean countries (FUINHAS et al., 2017). The GDP is in local currency units (LCU). In the econometric analysis, Stata 14.2 and EViews 9.5 software were used.

The best econometric practices on macro panels recommend the realization of preliminary tests. The most common tests are: (i) Variance Inflation Factor (VIF), to verify if variables are multicollinear; (ii) Cross-sectional Dependence (CSD-test), to check the existence of cross-sectional dependence in the variables (PESARAN, 2004) - the null hypothesis of this test is the existence of cross-sectional independence; (iii) second-generation unit root test, CIPS-test, and the Fisher test (MADDALA; WU, 1999), to check the integration order of variables - the null hypothesis rejection CIPS-test, as well as Fisher test, is that all variables have a unit root or I(1); (iv) Westerlund-test, to check the cointegration of variables (WESTERLUND, 2007) - thus, to the realization of the Westerlund-test it is necessary that all variables in levels are I(1); and (v) Hausman (1978) specification test, which compares an estimator that is known to be consistent with an estimator that is efficient under the assumption being tested. This test will compare the Random Effects (RE) with Individual Fixed Effects (FE).

If the Hausman test points to the RE estimator it is necessary to apply the following specification test namely: (i) Breusch and Pagan Langrarian Multiplier test of independence (BREUSCH; PAGAN, 1980), to measure whether the variances across individuals are correlated. Indeed, in the case of the FE estimator, it is necessary to test the heterogeneity of the model. For this, the following estimators will be applied: (i) the Mean Group (MG); and (ii) Pooled Mean Group (PMG). These estimators let us verify the heterogeneity of parameters both in the short- and in the long-run. The MG estimator is a technique that creates regressions for each cross and computes and also averages coefficient to all individuals (FUINHAS et al., 2017). This estimator in the long-run average is consistent; however, this estimator is inefficient in the presence of slope homogeneity (PESARAN et al., 1999). Thus, the PMG estimator makes restrictions among cross-sections and adjusts speed term. This estimator is more efficient than the MG estimator in the existence of homogeneity in the long-run (FUINHAS et al., 2017). 
After the heterogeneity tests, it will be applied the following specification tests: (i) Friedman test (HOYOS; SARAFIDIS, 2006), to check the existence of contemporaneous correlation between cross-sections; (ii) Breusch and Pagan Langrarian Multiplier test of independence (BREUSCH; PAGAN, 1980), to verify if the variances across individuals are correlated; (iii) Wooldridge test (WOOLDRIDGE, 2002), to check the existence of serial correlation; (iv) Modified Wald test (GREENE, 2002), to identify the existence of groupwise heteroscedasticity in the residuals of a FE regression model; ( $v$ ) Durbin-Watson statistic test, to verify the presence of the first-order autocorrelation in the disturbances when all the regressors are strictly exogenous - the null hypothesis of the test is that there is no first-order autocorrelation (VERBEEK, 2008); and (vi) Baltagi-Wu LBI-test, to test serial correlation in the disturbance - the null hypothesis of the test is no first-order serial correlation (BALTAGI, 2008).

\section{METHODOLOGY}

The unrestricted error correction model (UECM) form of the Auto-Regressive Distributive Lag (ARDL) model was used. This model decomposes the total effects of variables both in their short- and long-run components (SRNIVASAN et al., 2012; NAIN et al., 2015; KAIS; MBAREK, 2015; FUINHAS et al., 2017). The model also generates consistent and efficient parameter estimates, and the inference of parameters can be performed with standard tests. The general UECM form of the ARDL model used in this empirical analyse follows the specification of Eq. (1):

$$
\begin{aligned}
& \Delta L C O 2_{i t}=\alpha_{1 i}+\delta_{2 i} \text { TREND }_{t}+\sum_{j=1}^{k} \varphi_{11 i j} \Delta L C O 2_{i t-j}+\sum_{j=0}^{k} \varphi_{12 i j} \Delta L I G_{i t-j}+\sum_{j=0}^{k} \varphi_{13 i j} \Delta L R E_{i t-j}+ \\
& +\sum_{j=0}^{k} \varphi_{14 i j} \Delta L P E_{i t-j}+\sum_{j=0}^{k} \varphi_{15 i j} \Delta L Y_{i t-j}+\chi_{11 i} L C O 2_{i t-1}+\chi_{12 i} L I G_{i t-1}+\chi_{13 i} L R E_{i t-1}+ \\
& +\chi_{14 i} L P E_{i t-1}+\chi_{15 i} L Y_{i t-1}+\varepsilon_{1 i t}
\end{aligned}
$$

where, $\Delta \mathrm{LCO} 2, \Delta \mathrm{LIG}, \Delta \mathrm{LRE}, \Delta \mathrm{LPE}, \Delta \mathrm{LY}$, and LCO2, LIG, LRE, LPE, $\mathrm{LY}$ are the variables in first-difference and levels respectively. $\alpha_{1 i t}$ is the intercept, and $\phi_{11 i t \ldots} \phi_{15 i t \ldots} \chi_{1 i t \ldots} \chi_{15 i t}$ are the parameters of variables, and $\varepsilon_{1 i t}$ is the error term of the model.

\section{PRELIMINARY TEST RESULTS}

This section shows the preliminary tests on the data to check the proprieties of the variables. The VIF-test and CSD-test were applied to check the presence of multicollinearity, and cross-sectional dependence. The results of the VIF-test points to the existence of low multicollinearity, where the "Mean VIF" of the variables in levels is 1.54, and in the first differences is 1.05. Indeed, all the results of the VIF-test are below the benchmark of 10. The CSD-test reveals the presence of cross-sectional dependence in the variables in levels, and in first differences, except to the $\Delta$ LRE variable, in first differences. The existence of cross-sectional dependence means that countries share the same characteristics. The acknowledgement of cross-sectional dependence is a necessary step to properly examine the stationarity of variables. The presence of cross-sectional dependence requires the application of second-generation unit root tests.

The outcomes of the CIPS-test indicate that the variables LIG, and LRE, in levels, "without trend", and "with the trend" are I(1). The CIPS-test indicates that all variables in first-differences "with the trend", and "without trend" are I(1). To determine whether the panel has RE or FE structure the Hausman test was performed 
To identify the presence of RE or FE in the model, the Hausman test was applied. This test has the null hypothesis that the best model is RE. The results of the Hausman test is statistically significant $\left(\chi_{5}^{2}=47.07\right)$ at $1 \%$. This result supports the selection of the FE model. Then, after the choice of the FE model, the Eq. (1) is converted in Eq. (2), by changing $\varepsilon_{1 i t}$, for $\theta_{i}+\beta_{i t}$, representing the FE model.

$$
\begin{aligned}
& \Delta L C O 2_{i t}=\alpha_{2 i}+\delta_{2 i} \operatorname{TREND}_{t}+\sum_{j=1}^{k} \varphi_{21 i j} \Delta L C O 2_{i t-j}+\sum_{j=0}^{k} \varphi_{22 i j} \Delta L I G_{i t-j}+\sum_{j=0}^{k} \varphi_{23 i j} \Delta L R E_{i t-j}+ \\
& +\sum_{j=0}^{k} \varphi_{24 i j} \Delta L P E_{i t-j}+\sum_{j=0}^{k} \varphi_{25 i j} \Delta L Y_{i t-j}+\chi_{21 i} L C O 2_{i t-1}+\chi_{22 i} L I G_{i t-1}+\chi_{23 i} L R E_{i t-1}+ \\
& +\chi_{24 i} L P E_{i t-1}+\chi_{25 i} L Y_{i t-1}+\theta_{i}+\beta_{i t}
\end{aligned}
$$

where, $\Delta \mathrm{LCO} 2, \Delta \mathrm{LIG}, \Delta \mathrm{LRE}, \Delta \mathrm{LPE}, \Delta \mathrm{LY}$, and LCO2, LIG, LRE, LPE, $\mathrm{LY}$, are the variables in first-difference and levels, respectively. $\alpha_{1 i t}$ is the intercept, and $\phi_{11 \text { it } \ldots} \phi_{15 \text { it ... }} \chi_{1 i t \ldots} \chi_{15 \text { it }}$ are the parameters of the variables, and $\theta_{i}+\beta_{i t}$ is the error term of the RE model.

To double-check the possible cointegration of variables in the model, the second-generation cointegration tests of Westerlund (2007) were used. The variables LIG, LRE, LPE, and LY were used in this test. To provide proper coefficients, standard error, coefficient intervals, and to disclose robust critical p-values, the bootstrapping method was used. The results of the Westerlund cointegration tests indicate that the null hypothesis of no cointegration of the series should not be rejected, except for the statistic Pt. Pt tests the statistics pool information overall cross-sectional units and the rejection of the null hypothesis is the evidence that supports panel cointegration.

\section{EMPIRICAL RESULTS}

The MG and PMG were used against the dynamic FE estimator (DFE). The decision about the most suitable model is done by computing a Hausman test. Table 2 shows the outcomes of the MG, PMG, and DFE estimators, as well as the Hausman tests. 
Table 2 - Heterogeneous estimators and Hausman tests

\begin{tabular}{|c|c|c|c|c|c|c|}
\hline \multirow{2}{*}{ Variables } & \multicolumn{6}{|c|}{ (Dependent Variable $\Delta \mathrm{LCO}$ ) } \\
\hline & \multicolumn{2}{|l|}{ MG } & \multicolumn{2}{|l|}{ PMG } & \multicolumn{2}{|l|}{ DFE } \\
\hline CONSTANT & 2.7538 & & 1.6612 & $* * *$ & -0.6753 & *** \\
\hline TREND & 0.0054 & & -0.0030 & ** & -0.0005 & \\
\hline$\Delta$ LIG & 0.0461 & & 0.0871 & & 0.0871 & \\
\hline$\Delta \mathrm{LRE}$ & -0.1581 & $\star *$ & -0.1315 & $* * *$ & -0.1492 & $* * *$ \\
\hline$\Delta \mathrm{LPE}$ & 0.8076 & $* \star *$ & 0.8228 & $\star \star \star *$ & 0.7039 & *** \\
\hline$\Delta \mathrm{LY}$ & 0.2249 & & 0.3065 & ** & 0.3294 & ** \\
\hline ECM & -0.8353 & $* * *$ & -0.4792 & $\star * *$ & -0.6753 & *** \\
\hline LIG & -0.3678 & & -0.0583 & & -0.1555 & * \\
\hline LRE & -0.3330 & * & -0.1014 & $\star \star \star *$ & -0.1800 & *** \\
\hline LPE & 1.2467 & $* * *$ & 1.1156 & $\star * *$ & 1.0194 & *** \\
\hline \multirow[t]{2}{*}{ LY } & -0.0879 & & 0.1317 & & 0.1735 & * \\
\hline & \multicolumn{2}{|c|}{ MG vs PMG } & \multicolumn{2}{|c|}{ PMG vs DFE } & \multicolumn{2}{|c|}{ MG vs DFE } \\
\hline Hausman tests & \multicolumn{2}{|c|}{ Chi2(11) $=16.16$} & \multicolumn{2}{|c|}{ Chi2(11) $=-30.77$} & \multicolumn{2}{|c|}{ Chi2(6) $=18.37 *$} \\
\hline
\end{tabular}

Notes: * denotes statistical significance at $10 \%$ level; Hausman results for $\mathrm{HO}$ : dif-ference in coefficients not systematic; ECM denotes error correction mechanism; the long-run parameters are computed elasticities; the Stata commands "xtpmg", and Hausman (with the options, alleqs constant) was used.

Fonte:

The FE estimator is appropriate, indicating that the panel is homogeneous. This result suggests that the variables share common coefficients and can be treated as a group. The Hausman tests support panel homogeneity, i.e. that FE is the better model. To back up the significance of FE parameters, a battery of specification tests was used. The specification tests point to the existence of cross-sectional dependence, the presence of the first-order autocorrelation, the presence of heteroscedasticity in the residuals, and first-order correlation in the disturbance and serial correlation in the disturbance. The Breusch-Pagan LM test cannot be carried out because the correlation matrix of the residuals is singular.

DFE, DFE robust standard errors (DFE-Robust), and DFE Driscoll and Kraay (DFE D.-K) were applied. The DFE D.-K. estimator generates robust standard errors for several phenomena found in the sample errors, namely heteroskedasticity, first-order autocorrelation, cross-sectional dependence, and contemporaneous correlation. Table 3 shows the short-run (semi-elasticities) and long-run (elasticities) parameters for the models DFE, DFE robust and DFE D.-K. The long-run elasticities were computed by dividing the coefficient of the variables by the coefficient of $\mathrm{LCO} 2$, both lagged once and multiplying the ratio by -1 (FUINHAS et al., 2017) 
Table 3 - Estimations results

\begin{tabular}{|c|c|c|c|c|}
\hline \multicolumn{5}{|c|}{ (Dependent Variable $\Delta \mathrm{LCO}$ ) } \\
\hline Variables & Coefficients & DFE & DFE Robust & DFE D.-K. \\
\hline CONSTANT & -0.6753 & & & \\
\hline TREND & -0.0005 & & & \\
\hline \multicolumn{5}{|c|}{ Short-run (semi-elasticities) } \\
\hline$\Delta$ LIG & 0.0871 & & & \\
\hline$\Delta$ LRE & -0.1492 & $* * *$ & $* * *$ & $* * *$ \\
\hline$\Delta \mathrm{LPE}$ & 0.7039 & $\star \star \star *$ & $\star * *$ & 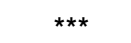 \\
\hline$\Delta \mathrm{LY}$ & 0.3294 & ** & $* \star *$ & ** \\
\hline \multicolumn{5}{|c|}{ Long-run (elasticities) } \\
\hline LIG(-1) & -0.1555 & * & ** & * \\
\hline $\operatorname{LRE}(-1)$ & -0.1800 & $* * *$ & $* * *$ & $* * *$ \\
\hline $\operatorname{LPE}(-1)$ & 1.0194 & $\star * \star$ & $* * *$ & $* \star *$ \\
\hline $\operatorname{LY}(-1)$ & 0.1735 & * & & $* * *$ \\
\hline \multicolumn{5}{|c|}{ Speed of adjustment } \\
\hline $\operatorname{ECM}(-1)$ & -0.6753 & $* * *$ & *** & *** \\
\hline
\end{tabular}

Notes: $* * * * *$, and $*$ denote statistically significant at $1 \%, 5 \%$ and $10 \%$ level, respec-tively. Hausman results for HO: Difference in coefficients not systematic. ECM de-notes an error correction mechanism. The long-run parameters are computed elasticities. The Stata commands xtpmg, and Hausman (with the sigmamore op-tion) were used. In the fixed effects the xtreg and xtscc Stata commands were used.

Fonte:

DFE, DFE Robust, and DFE-Driscoll and Kraay reveal the presence of long memory in the variables. The semi-elasticity of the index of globalisation $(\Delta \mathrm{LIG})$ shows that it does not exert a reduction on carbon dioxide emissions ( $\triangle \mathrm{LCO} 2$ ), and the elasticity of the index of globalisation (LIG) indicates a decrease of carbon dioxide emissions (LCO2) in -0.1555. The ECM term is statistically significant at $1 \%$ levels, and has a negative sign, indicating the presence of long memory/cointegration in the model. These outcomes signal Granger causality running from the statistically significant variables LRE, LPE, and LY to CO2 emissions (JOUINI, 2015; FUINHAS et al., 2017).

\section{ROBUSTNESS OF RESULTS}

The LAC region suffered several financial crises during the 1990 s, in the first half of the 2000 s, and from 2008 to 2009 . Several disruptive events occurred during the early 1980s and their effects extended almost throughout the entire decade. The second wave of events began with the Mexican crisis in 1994, and impacted almost all countries in the LAC region and continued with those in Brazil from 1998 to 1999, Uruguay in 1999, Argentina from 2001 to 2002, and again in Uruguay in 2001. A third wave began with the subprime crisis in the USA from 2008 to 2009, which impacted Belize in the period from 2008 to 2011, Chile in 2007, Ecuador in 2009, Jamaica in 2012, and Uruguay in 2009.

The results indicate that globalisation (LIG) mitigates carbon dioxide emissions (LCO2) in the long-run. The results also indicate that economic growth ( $\Delta L Y$ and $L Y$ ), and primary energy consumption ( $\triangle \mathrm{LPE}$ and LPE) increase carbon dioxide emissions, both in the short- and long-run. To assess the robustness of estimation results, dummy variables controlling for the main shocks that have had occurred in the LAC countries were added, namely: ID1993 (year 1993), ID1994 (year 1994), BLZ2008 (Belize year 2008), BLZ2009 (Belize year 2009), BLZ2010 (Belize year 2010), BLZ2011 (Belize year 2011), BOL1993 (Bolivia year 1993), BOL1994 (Bolivia year 1994), BRA1993 (Brazil year 1993), CHL2007 (Chile 
year 2007), ECU2008 (Ecuador year 2008), JAM2012 (Jamaica year 2012), URY1999 (Uruguay year 1999), URY2001 (Uruguay year 2001), URY2009 (Uruguay year 2009). These were introduced in the DFE, DFE Robust, and DFE D.-K models. Table 4 shows the results of semi-elasticities and elasticities for the DFE, DFE Robust, and DFE D.-K. models, including the dummy variables.

Table 4 - Estimation results with dummy variables

\begin{tabular}{|c|c|c|c|c|}
\hline \multicolumn{5}{|c|}{ (Dependent Variable $\Delta \mathrm{LCO}$ ) } \\
\hline & \multicolumn{4}{|c|}{ Fixed Effects } \\
\hline & Coefficient & DFE & DFE Robust & DFE D.-K. \\
\hline CONSTANT & 0.5343 & & & \\
\hline \multirow[t]{2}{*}{ TREND } & 0.0002 & & & \\
\hline & \multicolumn{4}{|c|}{ Dummy variables } \\
\hline ID1993 & 0.0519 & $* * *$ & *** & $* * *$ \\
\hline ID1994 & -0.0560 & $\star \star * *$ & *** & *** \\
\hline BLZ2008 & 0.4894 & $* * *$ & $* \star *$ & $* * *$ \\
\hline BLZ2009 & -0.5056 & $\star \star \star *$ & $* * *$ & $* \star *$ \\
\hline BLZ2010 & -0.1658 & $* * *$ & $* * *$ & $* * *$ \\
\hline BLZ2011 & -0.1618 & $\star \star \star *$ & $* \star *$ & $* \star *$ \\
\hline BOL1993 & 0.1885 & $* * *$ & $* * *$ & $* * *$ \\
\hline BOL1994 & 0.1408 & $* * *$ & $* * *$ & $* * *$ \\
\hline BRA1993 & 0.1856 & $* * *$ & $* * *$ & $* * *$ \\
\hline CHL2007 & -0.1376 & $\star \star \star *$ & $* * *$ & $* * *$ \\
\hline ECU2008 & -0.1173 & $\star \star \star *$ & $* * *$ & $* * *$ \\
\hline JAM2012 & 0.2365 & $* * *$ & 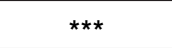 & $* * *$ \\
\hline URY1999 & 0.1281 & $* * *$ & $* * *$ & $* * *$ \\
\hline URY2001 & -0.2108 & $* * *$ & $* * *$ & $* * *$ \\
\hline \multirow[t]{2}{*}{ URY2009 } & 0.1412 & $\star \star \star *$ & $* \star *$ & *** \\
\hline & \multicolumn{4}{|c|}{ Short-run (semi-elasticities) } \\
\hline$\Delta$ LIG & 0.0582 & & & \\
\hline$\Delta$ LRE & -0.1415 & $\star \star \star *$ & $\star \star * *$ & $\star * \star$ \\
\hline$\Delta \mathrm{LPE}$ & 0.9340 & *** & $* \star *$ & *** \\
\hline \multirow[t]{2}{*}{$\Delta \mathrm{LY}$} & 0.1099 & & & * \\
\hline & \multicolumn{4}{|c|}{ Long-run (elasticities) } \\
\hline LIG(-1) & -0.1581 & ** & ** & * \\
\hline $\operatorname{LRE}(-1)$ & -0.1230 & $\star \star \star *$ & $* * *$ & $* * *$ \\
\hline $\operatorname{LPE}(-1)$ & 0.9948 & $* * *$ & $* * *$ & $* * *$ \\
\hline \multirow[t]{2}{*}{$\operatorname{LY}(-1)$} & 0.1608 & ** & ** & $* * *$ \\
\hline & \multicolumn{4}{|c|}{ Speed of adjustment } \\
\hline $\operatorname{ECM}(-1)$ & -0.5310 & $* * *$ & $* * *$ & $* * *$ \\
\hline
\end{tabular}

Notes: $* * *, * *$, and $*$ denotes statistically significant at $1 \%, 5 \%$, and $10 \%$ level, re-spectively. In the fixed effects, the xtreg, and xtscc Stata commands were used.

Fonte:

The shocks (dummy variables) are statistically significant at $1 \%$ level. Furthermore, as can be seen by comparing Tables 3 and 4, the ECM, with shocks, converge less in the long-run to equilibrium, compared to the ECM without shocks. Despite this reduction in the convergence to equilibrium, the model still proves to be robust, even in the presence of shocks. 


\section{DISCUSSION}

The economic behaviour of the LAC countries seems to suggest that they share similar ways of acting. The presence of CSD in levels for LIG and LRE denotes that globalisation and renewable electricity consumption were a common trend for the thirteen LAC countries analysed. The CSD in first differences is present in all variables, signalling that LAC countries tend to behave in the same way with respect to each variable.

The FE estimator proved to be more appropriate than the heterogeneity estimators, revealing that no slope heterogeneity is present in the model. Indeed, the results achieved by the MG, PMG, and DFE estimators are different, showing that the relationship between explanatory variables and $\mathrm{CO}_{2}$ emissions depends on the estimator used.

In the long-run, and by the presence of shocks, renewable electricity consumption exerts a mitigating effect on $\mathrm{CO}_{2}$ emissions, but primary energy consumption does not incorporate efficiency in electricity use. Indeed, primary energy consumption has an elasticity above one. Thus, in the long-run, the moderation of $\mathrm{CO}_{2}$ emissions depends on the consumption of renewable electricity. In the short-run, primary energy consumption and economic growth augment $\mathrm{CO}_{2}$ emissions, but only with semi-elasticities below one (respectively 0.7039 and 0.3294 ). In LAC countries, one can conclude that economic growth is not the main contributor to $\mathrm{CO}_{2}$ emissions from energy consumption (electric power sector). Renewable electricity consumption can mitigate $\mathrm{CO}_{2}$ emissions. The high error correction mechanism $(-0.6753)$ reveals that the model converges to long-run equilibrium very quickly.

When we consider the shocks that have beset the LAC countries, what stands out is the size of the disturbance this caused in $\mathrm{CO}_{2}$ emissions. This evidence shows that the analysis of LAC countries should compare the results of these two situations. Indeed, the removal of shocks, by the inclusion of impulse dummies in the model, revealed that all the variables are statistically significant in the long-run. In the short-run, only the two variables directly related to electricity generation are statistically significant (economic growth ceased to be statistically significant). Renewable electricity consumption exerts an effect on the mitigation of $\mathrm{CO}_{2}$ emissions, and primary energy consumption contributes to $\mathrm{CO} 2$ emissions, but with a greater contribution than when the shocks were included in the estimation. These results confirm the hypothesis that globalisation, in the long-run, via trade openness, promotes technological enhancement, thus contributing to a decrease of environmental degradation by mitigating $\mathrm{CO}_{2}$ emissions. These results reinforce and are consistent with the existing literature (SHAHBAZ et al., 2016; HALICIOGLU; KETENCI, 2016; BELADI; OLADI, 2011). Additionally, as expected, the semi-elasticities and elasticities of economic growth ( $L Y$ and $\triangle \mathrm{LY}$ ), and primary energy consumption (LPE and $\triangle \mathrm{LPE}$ ) increase carbon dioxide emissions in either the short- or long-run.

\section{CONCLUSIONS AND POLICY IMPLICATIONS}

The focus of this article is the study of the impact of globalisation on carbon dioxide emissions in Latin America and Caribbean countries for the period from 1991 to 2012. The panel ARDL methodology was used to decompose total effects in both their short- and long-run components. The initial diagnostic tests prove the presence of heteroscedasticity, cross-sectional dependence, and first-order autocorrelation. The robustness of the model was assessed with the inclusion of the shocks that have plagued Latin America and Caribbean countries. The shocks were identified in two ways: by the analysis of shocks presented in literature, and by the analysis of the residuals, with the aim of detecting shocks not reported in literature. To handle these shocks, the main model was augmented with impulse dummies. 
The evidence that globalisation contributes to the reduction of carbon dioxide emissions was found in this investigation. A possible explanation of this result is that the process of globalisation causes technological enhancement in LAC countries, which contributes to a decrease in environmental degradation. Globalisation has other implications, such as the transfer of responsibility from the state to the private sector, where this transfer corresponds to the shifting of regulatory attributes to independent governmental regulatory authorities, in other words, "regulation for competition". Indeed, this transference has as its consequence: improvement of energy efficiency, diversification of energy sources with the inclusion of renewable sources in the energy matrix, and energy supply routes, and the possibility of reducing energy prices for consumers in a scenario of high oil and gas prices.

\section{ACKNOWLEDGEMENTS}

CeBER R\&D unit funded by national funds through FCT - Fundação para a Ciência e a Tecnologia, I.P., project UIDB/05037/2020.

\section{REFERENCES}

AL-MULALI, U.; TANG, C.F.; OZTURK, I. Estimating the environment Kuznets curve hypothesis: Evidence from Latin America and The Caribbean countries. Renewable and Sustainable Energy Reviews, n.50, p. 918-924. doi: 10.1016/j.rser.2015.05.017, 2015.

BALTAGI, B.H. Econometric analysis of panel data. Fourth Edition, Chichester, UK: John Wiley \&Sons. URL: http://www1.tecnun.es/biblioteca/2009/ene/libmat1.pdf, 2008.

BALTAGI, B.H; ANSELIN, L. Spatial econometrics: In a companion to theoretical econometrics. Blackwell: Oxford, p. 310-330. doi:10.1002/9780470996249.ch15, 2001.

BELADI, H.; OLADI, R. Does trade liberalization increase global pollution?. Resource and Energy Economics, v. 33, n. 1, p. 172-178. doi: 10.1016/j.reseneeco.2010.04.009,2011.

BREUSCH, T.S; PAGAN A.R. The Lagrange Multiplier Test and Its Applications to Model Specification Tests in Econometrics. Review of Economic Studies, n. 47, p. 239-53. URL: http://www.jstor.org/ stable/2297111, 1980.

DRISCOLL, J.; KRAAY, A.C. Consistent covariance matrix estimation with spatially dependent data. Review of Economics and Statistics, v. 80, n. 4, p. 549-560. doi: 10.1162/003465398557825, 1998.

EDWARDS, S. Globalisation, Growth and Crises: The View from Latin America. National Bureau of Economic Research. Working Paper 14034. URL: http://www.nber.org/papers/w14034, 2008.

FUINHAS, J.A.; MARQUES, A.C.; KOENGKAN, M. Are renewable energy policies upsetting carbon dioxide emissions? The case of Latin America countries. Environmental Science and Pollution Research, v. 24, n. 17, p. 15044-15054. doi: 10.1007/s11356-017-9109-z, 2017.

GREENE, W. Econometric Analysis. Upper Saddle River, New Jersey: Prentice--Hall. 
GROSSMAN, G.; KRUEGER, A. Environmental impacts of a North American free trade agreement. National Bureau of Economic Research, working paper WP3914. Cambridge, Massachusetts. doi: 10.3386/w3914, 2002, 1991.

HALICIOGLU, F.; KETENCI, N. The impact of international trade on environmental quality: The case of transition countries. Energy, v. 109, n. 15, p. 1130-1138. doi: 10.1016/j.energy.2016.05.013, 2016.

HOYOS, R.E.; SARAFIDIS, V. Testing for cross-sectional dependence in panel-data models. The Stata Journal, v. 6, n. 4, p. 482-496. Available in: http://www.stata-journal.com/sjpdf.html?articlenum=st0113,2016.

JOUINI, J. Economic growth and remittances in Tunisia: Bi-directional causal links. Journal of Policy Modelling, v. 37, n. 2, p. 355-373. doi: 10.1016/j.jpolmod.2015.01.015, 2015.

KAIS, S.; MBAREK, M.B. Dynamic relationship between CO2 emissions, energy consumption and economic growth in three North African countries. International Journal of Sustainable Energy. doi: 10.1080/14786451.2015.1102910, 2015.

MADDALA, G.S.; WU, S. A comparative study of unit rood test with panel data a new simple test. Oxford Bulletin of Economics and Statistics, v. 61, n. 1., p. 631-652. doi: 10.1111/1468-0084.0610s1631,1999.

MAGAZZINO, C. The relationship between $\mathrm{CO} 2$ emissions, energy consumption and economic growth in Italy. International Journal of Sustainable Energy, v. 35, n. 6, p. 884-857. doi:10.1080/14786451.20 14.953160, 2014.

NAIN, M.Z.; AHMAD, W.; KAMAIAD, B. Economic growth, energy consumption and CO2 emissions in India: a disaggregated causal analysis. International Journal of Sustainable Energy. doi: 10.1080/14786451.2015.1109512, 2015.

PESARAN, M.H. General diagnostic tests for cross-section dependence in panels. The University of Cambridge, Faculty of Economics. Cambridge Working Papers in Economics n. 0435. URL: http://www. econ.cam.ac.uk/research/repec/cam/pdf/cwpe0435.pdf, 2004.

PESARAN, M.H.; SHIN, Y.; SMITH, R.P. Pooled mean group estimation of dynamic heterogeneous panels. Journal of American Statistical Association, v. 94, n. 446, p. 621-634. URL: http://www.jstor. org/stable/2670182, 1999.

SHAHBAZ, M.; KHAN, S.; ALI, A.; BHATTACHARYA, M. The Impact of Globalization on CO2 Emissions in China. The Singapore Economic Review, n. 62. doi: 10.1142/S0217590817400331, 2015.

SHAHBAZ, M.; KHRAIEF, N.; UDDIN, G.S.; OZTURK, I.Environmental Kuznets curve in an open economy: A bounds testing and causality analysis for Tunisia. Renewable and Sustainable Energy Reviews, v. 34, p. 325-336. doi: 10.1016/j.rser.2014.03.022, 2014.

SHAHBAZ, M.; NASREEN, S.; AHAMED, K.; HAMMOUDEH, S.Trade openness-carbon emissions nexus: The importance of turning points of trade openness for country panels. Energy Economics, v. 61, p. 221-231. doi: 10.1016/j.eneco.2016.11.008,2017.

SHAHBAZ, M.; OZTURK, I.; AFZA, T.; ALI, A. Revisiting the environmental Kuznets curve in a global economy. Renewable and Sustainable Energy Reviews, v. 25, p. 494-502. doi: 10.1016/j.rser.2013.05.021, 2013. 
VERBEEK, M.A. A Guide to Modern Econometrics. John Wily \& Sons LTD, $3^{\text {rd }}$ Edition. ISBN: 978-0-47051769-7, 2008.

WESTERLUND, J. Testing for error correction in panel data. Oxford Economics and Statistics, v. 32, n. 2, p. 217-224. doi: 10.1111/j.1468-0084.2007.00477. x, 2007.

WOOLDRIDGE, J. M. Econometric analysis of cross-section and panel data. Cambridge, Massachusetts: The MIT Press, 2002.

ZILIO, M. Curva de Kuznets ambiental, a validez de sus fundamentos en países en desarrollo. Cuadernos de Economía, v. 35, n. 97, p. (97):43-54. doi: 10.1016/S0210-0266(12)70022-5, 2002. 